\title{
论文
}

\section{基于D-D/D-T中子源的中子受激辐射计算机断层扫 描成像的比较研究}

\author{
赵亮，范亚明，董明，李英帼，王天泉，李中星，佟林格，尹永智”，陈熙萌 \\ 兰州大学核科学与技术学院, 兰州 730000 \\ *联系人, E-mail: yinyzh@1zu.edu.cn
}

收稿日期：2017-10-04; 接受日期：2017-10-31; 网络发表日期：2017-12-27

国家自然科学基金(编号: 11305083)和兰州大学中央高校基本科研业务费专项(编号: 1zujbky-2016-27)资助

摘要 对比研究了 D-D和D-T中子源在中子受激辐射计算机断层扫描成像(NSECT)中的应用, 建立了 TiT/TiD靶、 水体模内放置/未放置铁球4种计算模型, 并利用MCNP程序分别模拟了 D-D, D-T中子源产生 2.5 和 $14 \mathrm{MeV}$ 左右中 子束在该系统中的中子输运过程，记录并获得了出射中子和特征 $\gamma$ 射线通量分布及能谱图，该研究对中子成像方 面中子源的选择及平台的搭建有指导作用. 从出射中子和特征 $\gamma$ 射线通量分布发现, 激发的特征 $\gamma$ 射线会保持与入 射中子束同样的前倾方向，为了得到尽可能多的特征 $\gamma$ 射线，确定了在 D-D和 D-T两种中子源成像中，实验上应该 在 $Z=0$ 的平面上与中子束传播方向呈 $43.6^{\circ}-50.9^{\circ}$ 范围内布置 $\gamma$ 射线探测器. D-D和D-T两种中子源的NSECT高能 $\gamma$ 探测器最佳的放置位置稍有不同, 但都需要保持在 $43.6^{\circ}-50.9^{\circ}$ 的范围内. 从特征 $\gamma$ 射线能谱发现, ${ }^{56} \mathrm{Fe}$ 和 ${ }^{16} \mathrm{O}$ 对应的 特征峰能量与模拟数据的激发能完全吻合, 证明了NSECT技术识别元素的能力, 很有可能在追踪治疗过程以及研 究活体(包括人体)分子过程中踣露头角.

关键词 中子受激辐射计算机断层扫描成像, 特征 $\gamma$ 射线, 出射中子, MCNP

PACS: 47.27.-i, 47.27.Eq, 47.27.Nz, 47.40.Ki, 47.85.Gj

\section{1 引言}

中子受激辐射计算机断层扫描成像(Neutron Stimulated Emission Computed Tomography, NSECT)是 新发展的除核磁共振成像(Magnetic Resonance Imaging, MRI) 以外另一种具备元素识别能力的三维断层 成像方法 ${ }^{[1-3]}$. NSECT技术的基本原理是利用一快中 子束照射样品, 入射中子束与靶核主要发生散射作用 过程; 如果散射是非弹性的，靶核会被激发到更高的
能级态，随后会迅速退激到低能级，同时放出非弹性 散射 $\gamma$ 射线，其能量大小等于两个能级间的能量差值， 反映靶核的性质; 已知同位素的能级是一定且唯一的, 因此发射的非弹性 $\gamma$ 射线对于发射核素是特征的, 对获 取的 $\gamma$ 射线进行图像重建, 就能够得到样品的断层图像 并反映元素的组成和浓度. NSECT极有希望发展成为 一项新的影像诊断技术, 在小动物乃至人体上开展研 究和应用.

早期的研究表明，正常组织细胞在发生病变和癌

引用格式: 赵亮, 范亚明, 董明, 等. 基于D-D/D-T中子源的中子受激辐射计算机断层扫描成像的比较研究. 中国科学: 物理学 力学 天文学, 2018, 48: 022001 Zhao L, Fan Y M, Dong M, et al. A comparative study of neutron stimulated emission computed tomography based on D-D/D-T neutron source (in Chinese). Sci Sin-Phys Mech Astron, 2018, 48: 022001, doi: 10.1360/SSPMA2017-00279 
细胞在形成时, 其化学成分和周边的化学环境(如供血 等)都显示出一些变化, 如胸、肺、直肠中良性组织和 恶性组织中的微量元素的浓度有着很大的区别，包括 血色沉着病(铁元素超标)、威尔逊病(铜的浓度不正 常) 等 ${ }^{[3,4]}$. 而具备元素识别能力的NSECT技术有可能 在这个阶段对细胞的病变和癌症的发生作出可靠的判 断，从而发展出一种新的诊断和追踪治疗过程的方法, 以及研究活体(包括人体)分子过程的新技术.

NSECT系统的建立、应用到被推广依然存在诸 多难点, 实现NSECT至少需要3个要素: (1) 中子源; (2) 具备 $(n, \gamma)$ 甄别的高能位置灵敏 $\gamma$ 探测器; (3) 能够使入 射中子束或高能 $\gamma$ 探测器满足断层扫描成像要求的几 何阵列 ${ }^{[1]}$. 目前主要是美国杜克大学(Duke University) 和中国科学技术大学等研究组在开展NSECT方面的 研究工作, 涉及了在肝脏、脑癌、乳腺癌等方面的研 究 $^{[5-7]}$

本文针对NSECT系统的前端组件进行了设计和 排列, 并利用MCNP(Monte Carlo N-Particle Transport Code)程序 ${ }^{[8]}$ 分别模拟了 D-D, D-T中子源产生 2.5 和 14 $\mathrm{MeV}$ 左右中子束在该系统中 (对水体模内放置/不放置 铁球)的中子输运过程, 从而对实验平台的搭建作出指 导, 探讨在兰州大学强流中子发生器平台上开展 NSECT实验的可行性.

\section{2 材料和方法}

由于中子与物质相互作用比较特殊且输运过程相 当复杂, 轰击靶核发生非弹性散射所产生的特征 $\gamma$ 射线 出射角分布很广泛，故在目前的实际研究中普遍采用 蒙特卡罗数值模拟方法 ${ }^{[9-14]}$. 该方法是利用随机数进 行统计试验，以求得的统计特征值(如均值、概率等) 作为待求解问题的数值解. 蒙特卡罗方法归结为 3 个 主要步骤: (1) 构造或描述概率过程; (2) 实现从已知 概率分布抽样; (3) 建立各种估计量. 文中利用MCNP 软件包对NSECT系统的准直端中子与样品作用、中 子和 $\gamma$ 射线探测等进行了模拟. MCNP是一套计算粒子 输运过程的蒙特卡罗模拟计算程序，这个程序需要用 户通过输入INP文件给出如图1所示的计算模型示意 图，该系统包括 TiT靶/TiD靶、对称双雉形中子准直 器、水体模(有/无铁球)、探测器、屏蔽墙等.

由于 D-D, D-T反应产生的中子源并非单能的点

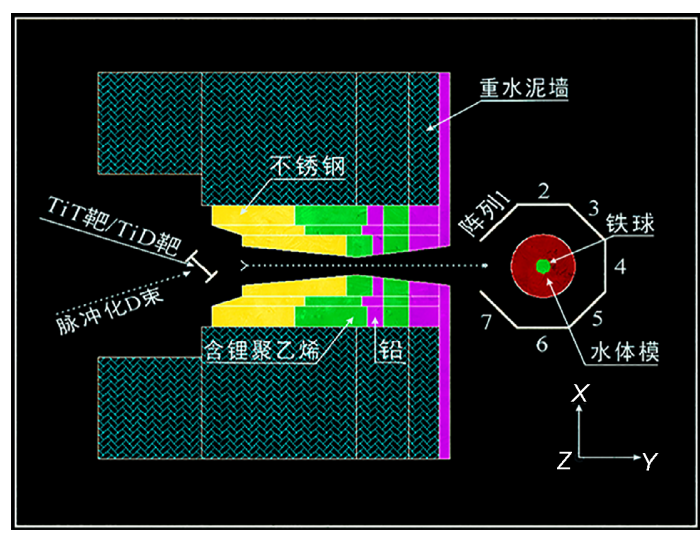

图 1 (网络版彩图) 由Vised应用程序生成的 $Y$ - $X$ 平面NSECT 系统计算模型示意图

Figure 1 (Color online) A two-dimension $(Y-X)$ schematic diagram of NSECT system calculation model which is generate from Vised Application Program.

源，而是具有一定的角分布和中子能谱. 为了更精确 地描述D-D, D-T中子源, 就有必要对D束打厚的TiT/ $\mathrm{TiD}$ 靶的出射中子能谱和角分布进行模拟研究, 将得 到的中子能谱和角分布数据输入到INP文件的通用源 描述卡中，来控制该系统中中子能量和角分布的抽样， 从而使得NSECT系统中模拟的入射中子束的能量和 角分布更接近于实际.

加速器中子源由于中子产额高和靶点小的优点, 其在NSECT系统中可以不需要特殊的准直系统, 但是 从保护电子学器件和辐射防护的角度, 对D-D, D-T中 子的屏蔽是有必要的. 通过对不同开孔方式的准直器 中子束特性对比 ${ }^{[15,16]}$, 选取准直效果和单一性方面较 好的对称双雉形作为准直器的开孔方式. 此外, 设置 准直屏蔽系统还起到提高水体模位置的中子注量率和 对产生的中子束流进行准直的作用. 研究表明, 由重金 属、聚乙烯和铅等材料组合而成的屏蔽体对快中子和 $\gamma$ 射线有较好的屏蔽效果 ${ }^{[17]}$.

屏蔽墙选择质量密度为 $3.5 \mathrm{~g} / \mathrm{cm}^{3}$ 的重水泥墙和铅 的组合, 重水泥墙的优势在于与已经经过屏蔽准直系 统慢化的中子相互作用产生的伴生 $\gamma$ 射线会少很多. 同 时, 因为后端有了铅的存在就能够很好地屏蔽伴生 $\gamma$ 射 线, 从而防止被探测器俘获到影响特征 $\gamma$ 射线计数.

靶体选择替代人体组织的圆柱体水体模, 并在水 体模几何中心放置铁球来仿真铁元素超标的病灶, 如 血色沉着病. 其中氢元素无特征 $\gamma$ 射线, 氧元素的主要 特征 $\gamma$ 射线的能量是 $6.134 \mathrm{MeV}$, 次要特征 $\gamma$ 射线的能量 
是 6.916 和 $7.112 \mathrm{MeV}$ ，铁元素的特征 $\gamma$ 射线能量是 $0.847 \mathrm{MeV}$.

水体模外围顺时针布置了 7 组阵列点探测器, 考虑 将阵列 1 和 7 布置在中子束射野范围外，从实验上避免 直接被快中子束辐射损伤的风险. 阵列 $1,2,3,4,5,6$, 7 分别布置了 $11,20,18,20,18,20,11$ 个点探测器, 并依 次从1-118编号, 每个点探测器的探测邻域球半径和相 邻间距分别是 0.1 和 $0.1 \mathrm{~cm}$.

\section{3 仿真结果}

对模拟结果进行数据提取、汇总、处理，得到 $\mathrm{D}$ D/D-T两种中子源、对有/无铁球模体的NSECT过程 中的出射中子和特征 $\gamma$ 射线的通量分布、比率分布以 及特征 $\gamma$ 射线能谱图.

\section{1 出射中子通量分布}

图2所示分别是D-D，D-T中子源在水体模内有/无 铁球的NSECT系统中的出射中子通量分布图. 由图2
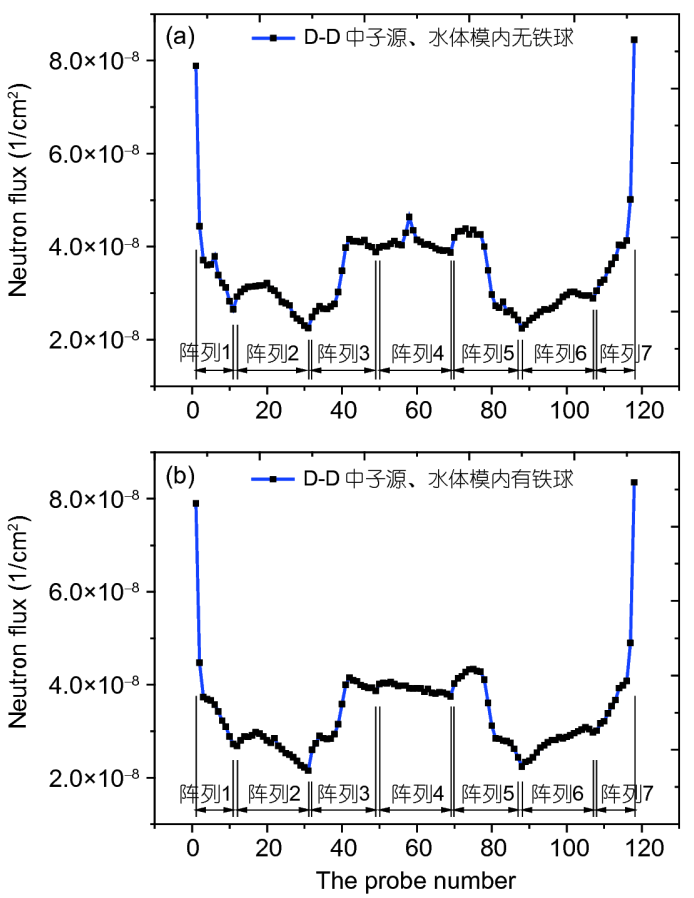

可以看到，D-T中子源的中子产额相对较高 $\left(\sim 10^{-7}\right)$, 主 要集中于主束的传播方向上，即使在水体模内放置铁 球依然很高. 由于在射野范围内快中子的穿透性很强, 就能够对人体深处的结构进行探测成像，而大部分其 他方法并没有这个效果; 由于铁的阻止本领比水大, 在水体模内放置铁球会产生如图2(d)所示主束方向上 的凹坑, 直接穿透的中子通量会有所减少, 入射中子与 靶核主要发生散射作用过程，因此在水体模内放置铁 球所探测到的出射中子通量会较未放置铁球时有所增 加. 快中子在与靶体发生非弹性散射时, 会产生激发效 应或者核反应，激发效应放出特征 $\gamma$ 射线，而核反应将 放出不同的粒子: 氦核、氛核、気核、质子等 ${ }^{[18,19]}$. 因 此，我们希望快中子在与水体模相互作用时尽可能少 地产生核反应，同时尽可能多地激发其主要特征 $\gamma$ 射线.

\section{2 特征 $\gamma$ 射线通量分布}

图3所示分别是D-D，D-T中子源在水体模内有/无 铁球的NSECT系统中的特征 $\gamma$ 射线通量分布图. 由图3
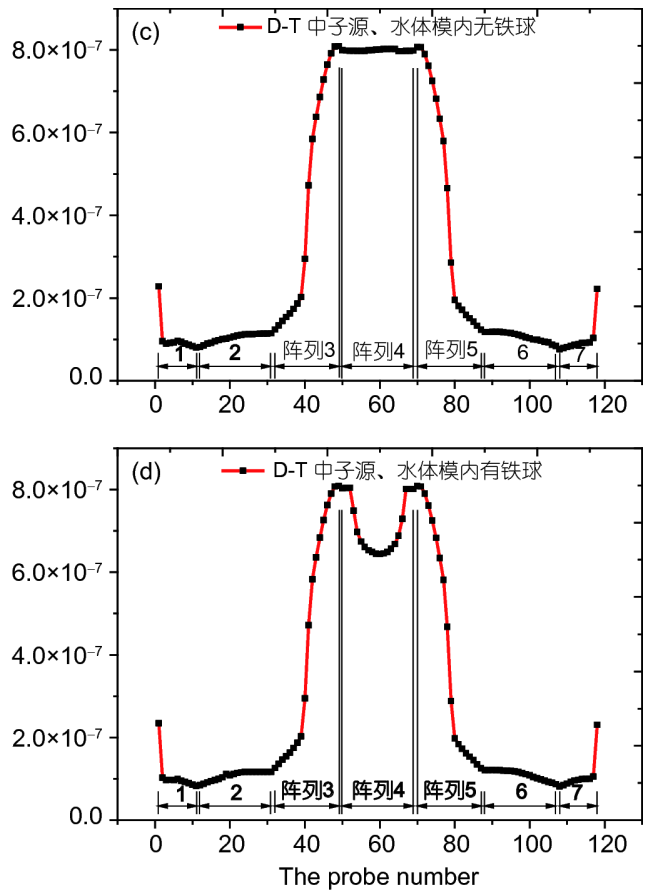

图 2 (网络版彩图)出射中子通量分布图. (a) D-D中子源、水体模内无铁球; (b) D-D中子源、水体模内有铁球; (c) D-T中子 源、水体模内无铁球; (d) D-T中子源、水体模内有铁球

Figure 2 (Color online) Outgoing neutron flux distribution map. (a) D-D neutron source, no iron ball is placed in the water model; (b) D-D neutron source, iron ball is placed in the water model; (c) D-T neutron source, no iron ball is placed in the water model; (d) D-T neutron source, iron ball is placed in the water model. 

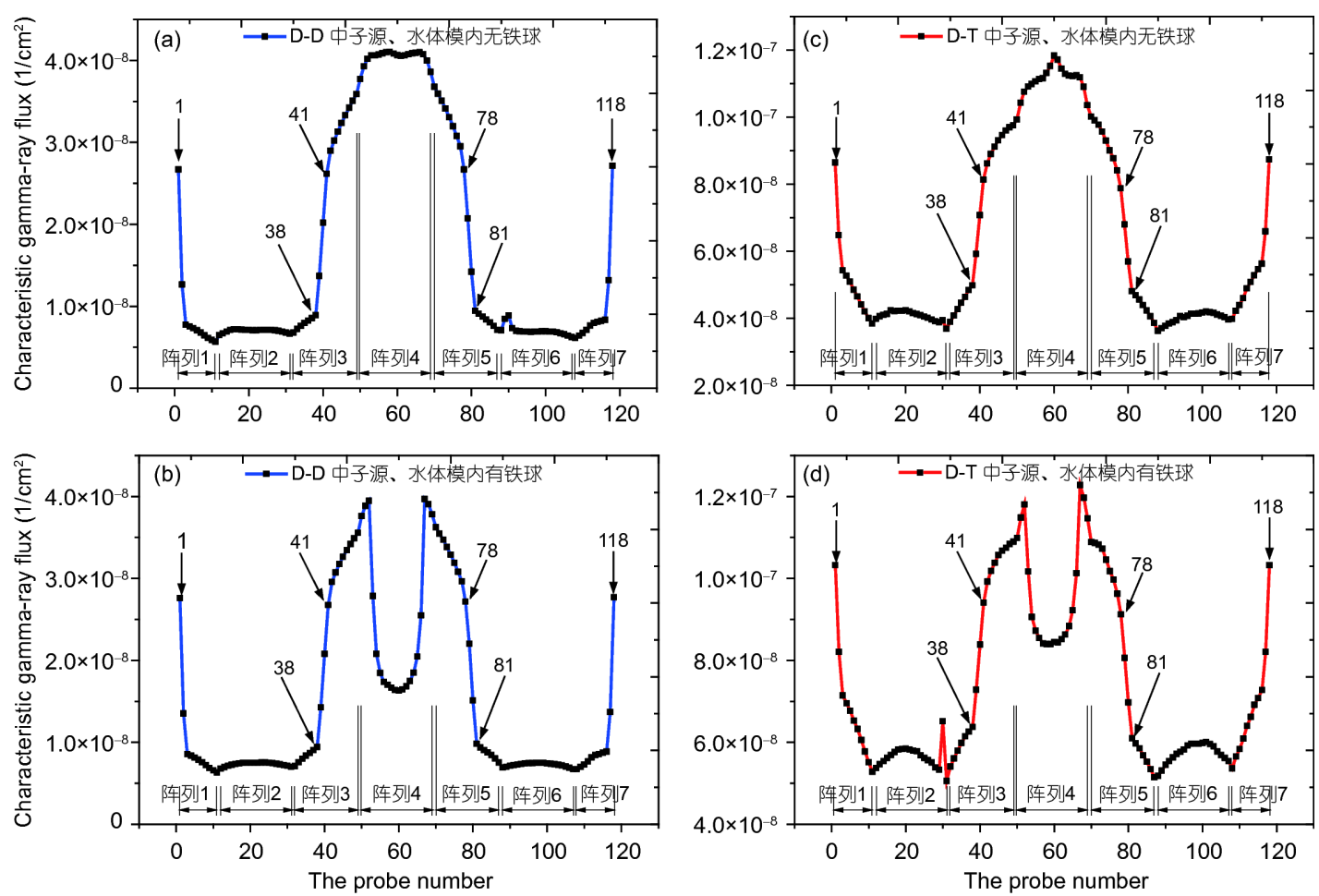

图 3 (网络版彩图)特征 $\gamma$ 射线通量分布图. (a) D-D中子源、水体模内无铁球; (b) D-D中子源、水体模内有铁球; (c) D-T中子 源、水体模内无铁球; (d) D-T中子源、水体模内有铁球

Figure 3 (Color online) Characteristic gamma-ray flux distribution map. (a) D-D neutron source, no iron ball is placed in the water model; (b) D-D neutron source, iron ball is placed in the water model; (c) D-T neutron source, no iron ball is placed in the water model; (d) D-T neutron source, iron ball is placed in the water model.

可以发现, D-T中子源由于中子产额高, 发生非弹性散 射激发的特征 $\gamma$ 射线相对较高 $\left(\sim 10^{-7}\right)$; 不论是 D-D中子 源还是D-T中子源，在水体模(代替人体组织)内有/无 铁球(代替肿瘤球)时，相互作用产生的特征 $\gamma$ 射线通量 保持与入射中子同样的前倾方向; 由于铁的阻止本领 比水大，在水体模内放置铁球就会产生如图3所示主 束方向上的凹坑. 直接穿透的中子通量会有所减少, 因而激发的特征 $\gamma$ 射线也会减少. 入射中子与靶核主要 发生散射作用过程，因此在水体模内放置铁球所探测 到的出射中子通量会较未放置铁球时有所增加，因而 激发的特征 $\gamma$ 射线也会增加. 在主束方向上，由于特征 $\gamma$ 射线并不具备快中子的穿透能力, 因此产生的凹坑较 出射中子通量更深.

水体模由氢、氧、铁元素构成: 氢元素无特征 $\gamma$ 射 线, 氧元素的主要特征 $\gamma$ 射线的能量是 $6.134 \mathrm{MeV}$, 次要 特征 $\gamma$ 射线的能量是 6.916 和 $7.112 \mathrm{MeV}$ ，铁元素的主要 特征 $\gamma$ 射线能量是 $0.847 \mathrm{MeV}$. 另外, 对人体以及日常生
活中常见的元素进行模拟和调研分析后发现，元素的 主要特征 $\gamma$ 射线能量范围在 $0.1-7 \mathrm{MeV}$ 之间. 由于铁元 素的核反应比在整个能量范围内都较低 $(<0.05)^{[20]}$, 故 在水体模中放置铁球的特征 $\gamma$ 射线通量较未放置铁球 的高. 核反应比反映了核反应的概率, 此值越小, 说明 核反应的概率越小, 越有利于将来在医学上的应用 ${ }^{[21]}$. 从中子通量和特征 $\gamma$ 射线通量分布可以发现, 对于 D-D 和D-T两种中子源, NSECT探测器的放置位置是相同 的. 模拟研究证明, 实验上应该在阵列 3 中 $38-41$ 号 探测位置处布置探测器, 即在 $Z=0$ 的平面上, 与中子束 传播方向呈 $43.6^{\circ}-50.9^{\circ}$ 的方向. 由于探测器布局的对 称性，也可在阵列 5 中 78-81号探测位置处布置探 测器.

\section{3 通量比率分布}

通常, 高能 $\gamma$ 探测器对中子也灵敏, 为了精确测量 特征 $\gamma$ 射线计数, 就必须减少散射中子或直接穿透的中 
子对探测器捕获特征 $\gamma$ 射线计数的干扰, 合理选择探测 器的布置位置, 才能得到可靠的成像数据. 模拟研究证 明，实验上应该在阵列3中38-41号探测位置处布置探 测器, 如表 1 是 38-41号探测位置处的特征 $\gamma$ 射线与出射 中子的通量比率. 由表1可以发现，D-D中子源、无Fe 和有 $\mathrm{Fe}$ 两种计算模型中 $38-41$ 号探测位置处的 $\gamma / \mathrm{n}$ 呈单 调递增; D-T中子源、无Fe和有 $\mathrm{Fe}$ 两种计算模型中 38 41 号探测位置处的 $\gamma / \mathrm{n}$ 呈先单调递增后单调递减. 因此, 对于D-D中子源在探测器合理布置范围内存在像 41 号 这样的最佳位置, 对于D-T中子源在探测器合理布置 范围内存在像39号这样的最佳位置.

\section{4 特征 $\gamma$ 射线典型能谱}

NSECT技术对入射中子的要求较高，在激发特征 $\gamma$ 射线的过程中, 所需要的中子能量较高, 即不能低于 其特征 $\gamma$ 射线的能量. 水体模由氢、氧、铁元素构成: 氢元素无特征 $\gamma$ 射线, 氧元素的主要特征 $\gamma$ 射线的能量 是 $6.134 \mathrm{MeV}$ ，次要特征 $\gamma$ 射线的能量是 6.916 和7.112 $\mathrm{MeV}$, 铁元素的主要特征 $\gamma$ 射线能量是 $0.847 \mathrm{MeV}$, 由于 D-D中子源能量较低 $(2.5 \mathrm{MeV})$, 适合识别铁、铜、 锌、镁等金属元素，却不足以激发氧元素的特征 $\gamma$ 射 线，所以文中分析了 D-T中子源 $(14 \mathrm{MeV})$ 激发的特征 $\gamma$ 射线能谱. 在NSECT系统计算模型中选用TiT靶，并 在水体模内几何中心位置不放置/放置铁球，进行模拟 得到如图4所示编号为40(NSECT成像合理探测范围内 的位置)的探测器探测的特征 $\gamma$ 射线能谱，并在能谱上 对水体模进行了元素识别和标记. 从模拟的能谱数据
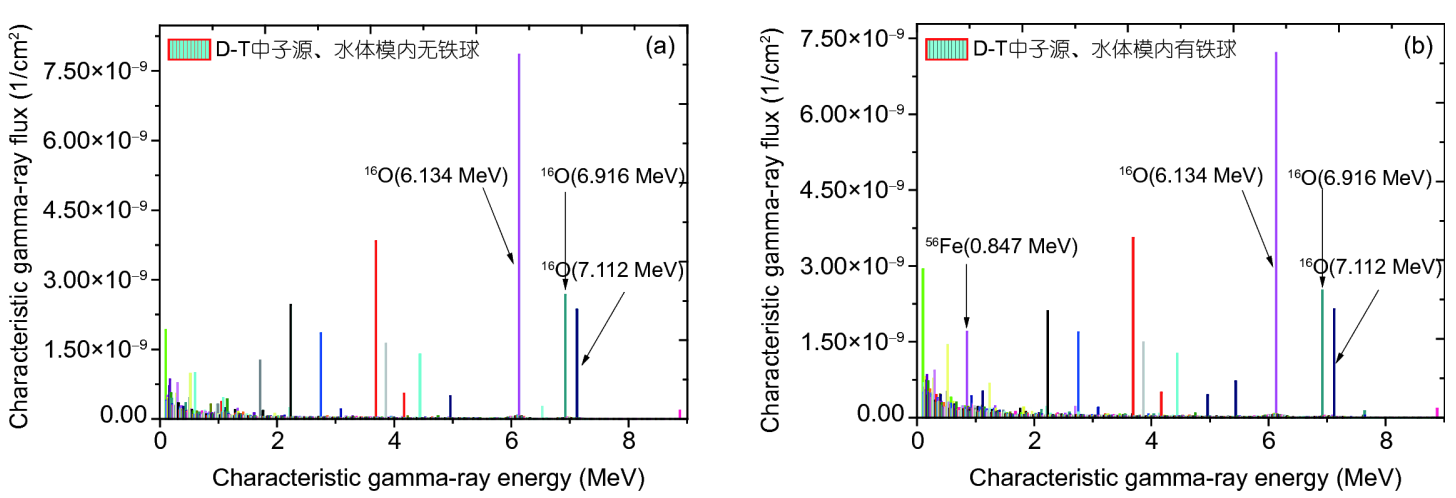

图 4 (网络版彩图)编号为40的探测器探测的特征 $\gamma$ 射线能谱. (a) D-T中子源、水体模内无铁球; (b) D-T中子源、水体模内有 铁球

Figure 4 (Color online) The characteristic gamma-ray energy spectrum of the detector which numbers for 40. (a) D-T neutron source, no iron ball is placed in the water model; (b) D-T neutron source, iron ball is placed in the water model.

表 1 探测器合理布置范围内的 $\gamma / n$ 通量比率分布

Table 1 The flux ratio distribution of characteristic gamma-ray and outgoing neutron in the reasonable detection range

\begin{tabular}{cccc}
\hline 中子源 & 探测器编号 & 无 $\mathrm{Fe}$ & 有 $\mathrm{Fe}$ \\
\hline \multirow{4}{*}{ D-D } & 38 & 0.3211 & 0.3207 \\
& 39 & 0.4535 & 0.4530 \\
& 40 & 0.5804 & 0.5802 \\
& 41 & 0.6582 & 0.6705 \\
\multirow{2}{*}{ D-T } & 38 & 0.2675 & 0.3400 \\
& 39 & 0.2919 & 0.3586 \\
& 40 & 0.2401 & 0.2847 \\
\hline
\end{tabular}

发现特征峰能量与靶体元素的激发能对应一致，说明 NSECT具备元素识别和确定元素浓度的能力，通过确 定元素浓度就可以对例如血色沉着病(铁元素超标)、 威尔逊病(铜的浓度不正常)等疾病作出早期诊断，从 而发展出一种新的诊断技术.

\section{4 讨论和结论}

通过对 D-D/D-T中子源、水体模内放置/未放置铁 球 4 种计算模型的模拟研究，从出射中子和特征 $\gamma$ 射线 通量分布发现，激发的特征 $\gamma$ 射线会保持与入射中子束 同样的前倾方向, 当水体模内放置铁球时, 主束方向的 特征 $\gamma$ 射线和出射中子都会受到一定的阻碍, 其他方向 上的特征 $\gamma$ 射线通量会有所增加. 为了得到尽可能多的 
特征 $\gamma$ 射线, 38-41号探测器处是合理的探测位置, 进一 步证实实验上应该在阵列3中38-41号探测位置处布置 探测器，即在 $Z=0$ 的平面上，与中子束传播方向呈 $43.6^{\circ}-50.9^{\circ}$ 的方向, 由于探测器布局的对称性, 也可在 阵列 5 中 $78-81$ 号探测位置处 $\left(-43.6^{\circ}--50.9^{\circ}\right.$ 的方向上) 布置探测器 ${ }^{[17]}$. D-D和D-T两种中子源的NSECT高能 $\gamma$
探测器最佳的放置位置稍有不同，但都需要保持在 $43.6^{\circ}-50.9^{\circ}$ 的合理范围内. 从特征 $\gamma$ 射线能谱发现, 靶 体元素对应的特征峰能量与模拟数据的激发能完全吻 合，说明了基于D-T中子源的NSECT技术具备识别元 素的能力, 就很有可能在追踪治疗过程以及研究活体 (包括人体)分子过程中崭露头角.

\section{参考文献}

1 Floyd C E, Calvin H, Brian H, et al. Neutron stimulated emission computed tomography of stable isotopes. Proc SPIE, 2004, 5368: 248-255

2 Floyd Jr. C E, Bender J E, Sharma A C, et al. Introduction to neutron stimulated emission computed tomography. Phys Med Biol, 2006, 51: 33753390

3 Geraki K, Farquharson M J, Bradley D A. Concentrations of Fe, Cu and Zn in breast tissue: A synchrotron XRF study. Phys Med Biol, 2002, 47: 2327-2339

4 Geraki K, Farquharson M J, Bradley D A. X-ray fluorescence and energy dispersive X-ray diffraction for the quantification of elemental concentrations in breast tissue. Phys Med Biol, 2004, 49: 99-110

5 Lakshmanan M N, Kapadia A J. Quantitative assessment of lesion detection accuracy, resolution, and reconstruction algorithms in neutron stimulated emission computed tomography. IEEE Trans Med Imag, 2012, 31: 1426-1435

6 Rhee D J, Agasthya G A, Kapadia A J. Neutron stimulated emission computed tomography for brain cancer imaging. In: Proceeding of 2013 IEEE, Nuclear Science Symposium and Medical Imaging Conference (NSS/MIC). Seoul, 2013

7 Lakshmanan M N, Harrawood B P, Agasthya G A, et al. Simulations of breast cancer imaging using gamma-ray stimulated emission computed tomography. IEEE Trans Med Imag, 2014, 33: 546-555

8 Briesmeister J F. MCNP-A General Monte Carlo N-Particle Transport Code. Version 4C, LA-13709-M, 2000

9 Sharma A C, Harrawood B P, Bender J E, et al. Neutron stimulated emission computed tomography: A Monte Carlo simulation approach. Phys Med Biol, 2007, 52: 6117-6131

10 Kapadia A J, Harrawood B P, Tourassi G D. Validation of a Geant4 simulation of neutron stimulated emission computed tomography. Proc SPIE, 2008, 6913: 69133H

11 Sharma A C, Tourassi G D, Kapadia A J, et al. Design and development of a high-energy gamma camera for use with NSECT imaging: Feasibility for breast imaging. IEEE Trans Nucl Sci, 2007, 54: 1498-1505

12 Sharma A C, Turkington T G, Tourassi G D, et al. Near-field high-energy spectroscopic gamma imaging using a rotation modulation collimator. Nucl Instrume Meth Phys Res Sect B-Beam Interact Mater Atoms, 2008, 266: 4938-4947

13 Floyd C E, Bender J E, Harrawood B, et al. Breast cancer diagnosis using neutron stimulated emission computed tomography: Dose and count requirements. Proc SPIE, 2006, 6142: O1421

14 Kapadia A J, Sharma A C, Tourassi G D, et al. Neutron stimulated emission computed tomography for diagnosis of breast cancer. IEEE Trans Nucl Sci, 2008, 55: 501-509

15 Liu Y. Shielding Effect and the Background of the Experimental Hall of Neutron Generator (in Chinese). Dissertation for Masteral Degree. Lanzhou: Lanzhou University, 2011. 18-49 [刘洋. 中子发生器实验厅屏蔽效果及本底研究. 硕士学位论文. 兰州: 兰州大学, 2011. 18-49]

16 Liu Y, Yao Z E, Shen F, et al. Simulation of BSA design and beam characteristic for fast neutron radiography using a D-T neutron source (in Chinese). Nucl Tech, 2011, 34: 273-277 [刘洋, 姚泽恩, 沈飞, 等. D-T快中子照相准直屏蔽体设计及中子束特性的模拟研究. 核技术, 2011, 34: 273-277]

17 Zhao L, Li Z X, Yue S, et al. MCNP simulation study of neutron stimulated emission computed tomography system based on D-T neutron source 
(in Chinese). Sci Sin-Phys Mech Astron, 2017, 47: 43-50 [赵亮, 李中星, 岳松, 等. 中子受激辐射计算机断层扫描成像系统的MCNP模拟. 中 国科学: 物理学 力学 天文学, 2017, 47: 43-50]

18 Ding D Z, Ye C T, Zhao Z X, et al. Neutron Physics_Principles, Methods and Applications (in Chinese). Beijing: Atomic Energy Press, 2001 [丁 大钊, 叶春堂, 赵志祥, 等. 中子物理学——原理、方法与应用. 北京: 原子能出版社, 2001]

19 Tang X W. Particle Physics Experiment Method. Beijing: People's Publishing House, 1982 [唐孝威. 粒子物理实验方法. 北京: 人民出版社, 1982]

20 Tang S B. Research on Several Key Problems of Neutron Stimulated Emission Computed Tomography (in Chinese). Dissertation for Doctoral Degree. Anhui: University of Science and Technology of China, 2009. 20-26 [唐世彪. 中子受激辐射计算机断层扫描成像技术中若干关键问 题的研究. 博士学位论文. 安徽: 中国科学技术大学, 2009. 20-26]

21 Tang S B, Yin Z J, Zhu D M, et al. Simulation study of neutron stimulating elements: Carbon, oxygen, iron and copper (in Chinese). Nucl Tech 2007, 30: 189-191 [唐世彪, 阴泽杰, 朱大鸣, 等. 中子激发碳、氧、铁、铜的模拟研究. 核技术, 2007, 30: 189-191]

\title{
A comparative study of neutron stimulated emission computed tomography based on D-D/D-T neutron source
}

\author{
ZHAO Liang, FAN YaMing, DONG Ming, LI YingGuo, WANG TianQuan, \\ LI ZhongXing, TONG LinGe, YIN YongZhi ${ }^{*} \&$ CHEN XiMeng \\ School of Nuclear Science and Technology, Lanzhou University, Lanzhou 730000, China
}

In this paper, we investigated the applications of D-D and D-T neutron sources in Neutron Stimulated Emission Computed Tomography (NSECT). Four NSECT models were established, including the TiT/TiD targets to generate neutron sources and the presence/absence of iron balls in water phantom to mimic tumors. NSECT system was simulated by using MCNP software, in which the D-D and D-T neutron sources were generated, collimated, transported, and recorded. We studied flux distributions and typical spectrum of both outgoing neutrons and the characteristic gamma-rays for D-D and D-T NSECT. Results show that the optimized NSECT gamma-ray detector locations will be in the direction from $43.6^{\circ}$ to $50.9^{\circ}$ along the neutron beam propagation direction. The best NSECT gamma-ray detector locations for D$\mathrm{D}$ and D-T NSECT are slightly different, but in both cases the detectors should be aligned in the direction from $43.6^{\circ}$ to $50.9^{\circ}$. We found the characteristic peaks of ${ }^{56} \mathrm{Fe}$ and ${ }^{16} \mathrm{O}$ from the energy spectrum of characteristic gamma-ray. This demonstrates that NSECT has the ability to identify elements, which would be very useful in tracking the treatment process and in studying the molecular process of living body (including human-beings). This study gives a comprehensive understanding on the selection of neutron sources and the placement of gamma-ray detectors in NSECT applications.

neutron stimulated emission computed tomography, characteristic gamma-ray, outgoing neutron, MCNP

PACS: 47.27.-i, 47.27.Eq, 47.27.Nz, 47.40.Ki, 47.85.Gj

doi: $10.1360 /$ SSPMA2017-00279 